\title{
CHROMATOGRAPHIC EXAMINATIONS IN THE GAS NETWORK ODOURISED BY TETRAHYDROTHIOPHENE
}

\author{
ANALIZY CHROMATOGRAFICZNE \\ W SIECI GAZOWEJ NAWANIANEJ TETRAHYDROTIOFENEM
}

\begin{abstract}
The paper presents the results of the spread of the tetrahydrothiophene (THT) - used as odourant - in the gas network. Such analyses allow quick detection of leaks in networks, systems and devices of gas supply directly to consumers. The main goal of the study was to determine the effectiveness of the use of portable chromatograph and comparing it with a stationary odourant concentration analyser. Based on these studies, an attempt to determine the odouration zone for the selected city have been also taken. For this purpose, three series of measurements were made - in each series 13 points were analysed. Obtained results confirmed the effectiveness of the measurement a concentration of odourant in the gas network using a portable gas chromatograph - difference in relation to the stationary chromatograph ranged from 1.91 to $2.55 \%$.
\end{abstract}

Keywords: chromatograph, gas chromatography, gas network, odourant, tetrahydrothiophene, THT

\section{Introduction}

Natural gas is the fuel obtained from the earth's crust. The natural gas network consists of different pipelines witch have different conditions as well as goals [1]. The transmission line refers to a pipeline that transports gas from a collection line, usually under high pressure. Typically, the pipeline can carry gas at a speed of $11 \mathrm{~m} \cdot \mathrm{s}^{-1}$ at long distances. Distribution pipeline refers to a low pressure system that delivers gas to end users via local pipelines [1]. The majority of gas compounds is saturated hydrocarbons mix with odourless methane with is $90 \%$ volume of gas. It occurs in oil-gas or gas deposits. During the incineration, natural gas does not generate dust or solid waste with can be products of coal or oil usage. Due to its high energy properties, it is used in various industries, such as agriculture, trade and services, power industry, metallurgy, chemical and food industry, air conditioning, cogeneration and heating. Pipeline natural gas is the primary fuel of choice for distributed fuel cell-based power-generation systems due to its abundant supply and well-developed infrastructure. Natural gas is composed of low boiling hydrocarbons (mostly methane) and much smaller amounts of nitrogen, carbon dioxide, water vapour and sulphur compounds [2].

\footnotetext{
${ }^{1}$ Faculty of Building Services, Hydro and Environmental Engineering, Warsaw University of Technology, ul. Nowowiejska 20, 00-653 Warszawa, Poland

*Corresponding author: Miroslaw.Szydlowski@pw.edu.pl
} 
Possibility of environmental contamination by natural gas is relatively small. Due to the high flammability of methane, which is colourless, odourless and lighter than air gas and in order to prevent accidents related to unsealed installations, odourant is added into the gas network.

The odourisation of gas was started about 1880 in Germany [3, 4] to reduce fatalities resulting from escaping gas. Firstly, an odour was added to blue water gas (an industrial gas composed almost entirely of carbon monoxide and hydrogen) [5]. The first reported odourant was ethanethiol (EtSH) and nitrobenzene. Germany began small-scale odourisation since 1918, and, after short time, USA [4]. Odourant must have a characteristic smell, which will be alerting consumers of danger related only to the natural gas.

A properly selected odourant should:

- be characteristic, clear and has a recognizable fragrance with is unique to associate with "smell of gas";

- have extended exposure time and at the same time have low odour detection threshold;

- be resistant to chemical oxidation;

- relatively have chemical stability (it should not interact with the components flowing in the gas pipeline and with materials from which gas pipeline is made);

- have low sorption in soil;

- have a sufficiently high vapour pressure (in an attempt to gas in gas installation does not undergo to condensation as a result of pressure change in pipes);

- $\quad$ have fragrance that will not be to suppress by others compounds;

- does not need to be water down, which may create a corrosion.

In Russia, at all of the gas-distribution stations, the MNM (mixture of natural mercaptans) is used. It has the odour of hydrogen sulphide with a low perception threshold (partial odourant pressure is starting from $0.19 \mathrm{mg} \cdot \mathrm{m}^{-3}$ and above) [6]. In Italy, two gas odourants are used: one consists entirely of tetrahydrotiofene, whereas the other one is a mixture of three mercaptans, i.e. terbutyl mercaptan, isopropyl mercaptan and normalpropyl mercaptan ("TBM/IPM/NPM") [7]. Also, Capelli et al. evaluated the possibility of introducing a new, sulphur-free gas odourant (Gasodor ${ }^{\circledR}$ SFree). Sensorial tests were run comparing that odourant with the two traditional odourants: TBM/IPM/NPM and THT and with other "interfering" odours, in order to verify that the odour of the tested odourant is "characteristic". These results indicate that the odour of the S-Free odourant is not confused with other interfering odours [7]. In Chile, liquefied petroleum gas (LPG) is odorized with dimethyl sulphide and tert-butyl mercaptan at a rate of about 10 grams of odourant per 1 cubic meter of LPG [8].

In Poland, the most commonly used odourants are organic compounds with sulphur such as mercaptans and tetrahydrothiophene.

Tetrahydrothiophene - THT $\left(\mathrm{C}_{4} \mathrm{H}_{8} \mathrm{~S}\right)$ is an organic compound descended from cyclic thioether with high volatility. This is a colourless liquid with a characteristic and very intensive odour. It is highly flammable compound; autoignition temperature is $202{ }^{\circ} \mathrm{C}$, the boiling point $121{ }^{\circ} \mathrm{C}$, while the ignition temperature is only $15^{\circ} \mathrm{C}$. THT is water-soluble, however it can be harmful for water organisms, causing long and no beneficial changes in environment. It is not biodegradable and does not show any potential for bioaccumulation. THT is known for its more stable chemical characteristics than mercaptans as well as its ability to strongly resist for oxidation [9]. 
At the time of THT production it is possibility to obtain $98 \%$ of clear odourant. It is produced at the reaction between tetrahydrofuran or 1,4-butanediol with hydrogen sulphide.

The lower limit of perceptibility of odourant is $3.7 \mu \mathrm{g} \cdot \mathrm{m}^{-3}$ and compound itself is three times heavier than air. THT is highly irritating to the skin and mucous membranes. In the case of extended inhalation by humans, it causes respiratory irritation, embolism in the lungs, headache, dizziness, nausea and palpitations. In larger doses causes hyperactivity, liver damage, eventually leads to death resembling a drug overdose [10].

THT is the most resistant to pipeline oxidation. It has a gassy odour but low odour impact and poor soil penetrability. The low odour impact makes it difficult to over-odourise with THT. This compound may be used in pure form or as part of a blend with TBM (tertiary butyl mercaptan). THT is a "stand alone" odourant [11]. Its odour threshold measured by the triangle odour bag method is $0.00062 \mathrm{ppm}, \mathrm{v} / \mathrm{v}$ [12]. Capelli [7] wrote, that the quantity of odourants added to natural gas, despite being in the order of magnitude of some $\mathrm{mg} \cdot \mathrm{m}^{-3}$, is not negligible if compared to the TLV of $\mathrm{SO}_{2}$. The minimum concentrations of TBM/IPM/NPM and THT in the distributed gas in Italy are equal to $8 \mathrm{mg} \cdot \mathrm{m}^{-3}$ (TBM/IPM/NPM) and $32 \mathrm{mg} \cdot \mathrm{m}^{-3}$ (THT), corresponding to 2.3 and $8.9 \mathrm{ppm}$, respectively [7]. These considerations highlight the reasons why, in recent years, the possibility to introduce alternative, sulphur-free odourants is being studied $[13,14]$.

In many cases, on-site rapid analyses are required in many cases. The results may be important for human and animal safety and environmental protection, or a delay in the results of analysis can lead to considerable financial losses. Langford et al. wrote [15] that conventional sensor-based and chromatographic technologies are poorly suited to the instrumental analysis of odour due to chemical diversity of many important odourants, the high sensivity required to achieve human odour thresholds and dynamic nature of the odour itself. Therefore, for field applications of analytical chemistry, test methods, test tools, and components for rapid on-site tests are developed. Yashin [16] wrote, that leading chromatographic companies (Perkin-Elmer, Hewlett-Packard and Varian) have absorbed smaller companies that produced portable chromatographs (Photovac, Microsensor Technology, and Chrompack, respectively) and started investing in these fields [16]. Promising direction in the miniaturizing of chromatographs is the development of portable gas chromatographs (transportable or handheld) for on-site analysis [17]. Such instruments are gas or power operated. They are light, reliable, easy to operate, and provide rapid analyses, inter alia, gas-chromatographic field determinations of organochlorine pesticides, low-volatile organic compounds, and carbon dioxide [17]. Also, reduced sulphur compounds for odour examinations [18, 19] and other research of odourous impact assessments [20] were reported. Portable chromatographs like Photovac Voyager - designed to provide near-real time, accurate and precise monitoring of VOC and gases in connection with environmental remediation activities [21, 22] - are useful for the fast determination of tetrahydrothiophene in natural gas [23]. They are used for determination of emission from phytoplankton [24] or numerous plant species to the atmosphere [25-27]. De Hate et al. proceed real time monitoring program of early detection of short-term emissions and off-site migration of site-related TVOCs and respirable dust [28]. This analyser has 3 built-in GC columns with dual photoionization and electron capture detectors (PID/ECD). For fast GC analysis, the voyager contains up to 40 factory-programmed EPA listed VOCs. A full day of field data may be logged and then transferred to a PC. The Electron Capture Detector (ECD) makes it possible for the instrument to analyse for chlorinated compounds. 
When a flame photometric detector (FPD) is used instead of the PID, the instrument is capable of analysing for sulphur and phosphorus compounds.

\section{Materials and methods}

\section{Aim and scope of the study}

The main aim of this work is to present the efficiency of the use of a portable gas chromatograph - Voyager of Photovac in the gas network and to compare its performance with stationary analyser ANAT-M, only dedicated for THT. ANAT-M analyser is increasingly used in Poland - number of ANAT-M analysers actively operating in the field of object conditions was in 2017 nearly 250 [29]. Also, there was taken action to determine odourised zone for a city with a population of over 76600 inhabitants.

Before the main series of tests have started, the preliminary series of measurements had been performed. They allow to compare results recorded by Voyager and analyser of THT. In the main three series of research there was taken the gas material from 13 measuring points located in the whole city and its surroundings.

Research THT odourant in the gas mains and monitoring of this compound, allow for quick detection of leaks in installations, systems and gas devices, which is directly provide to customers. This operation is important for people and environmental safety. Topicality and significance of the present problems had contribute to be interested in a topic related to the practical use of portable gas chromatograph analysis of odourant compounds as THT for the needs of the Gas Industry.

\section{Object description}

The National Gas System established a rule that natural gas in the gas network should be well detectable. The degree of perceptibility of odour intensity should be $I=2$ in odour intensity scale (Table 1), when its concentration in the air is equal to 1 to 5 of the lower limit of perceptibility. This value was chosen for a person having ordinary ability to smell.

Odour intensity scale

\begin{tabular}{|c|c|}
\hline Odour intensity scale & Odour intensity \\
\hline 0 & palpable scent \\
\hline 0.5 & very faint scent (the lower limit of perceptibility) \\
\hline 1 & weak scent \\
\hline 2 & explicite scent (warning scent) \\
\hline 3 & a strong scent \\
\hline 4 & a very strong scent \\
\hline 5 & the upper limit of perceptibility \\
\hline
\end{tabular}

The city, with a population of over 76600 inhabitants, is provided from the odourised gas network from two stations and one is coming from the north, the other - from the south. The both odourised stations use injection methods in order to introduce the compound of THT concentration into the installation. This allows to equal distribution of odourant throughout the entire city and its surroundings. The whole, single odourised zone is being created. In case that one of the stations is not working properly, the other one, automatically, has to take over its functions of the maintenance of the appropriate level of concentration of odourant in the gas network. 
At the summer time between April and October, odourant is added to gas installation at the concentration of $15 \mathrm{mg} \cdot \mathrm{m}^{-3}$. At the winter period, November-March, concentration of the odourant in gas mains cannot be lower than $30 \mathrm{mg} \cdot \mathrm{m}^{-3}$. Two times per annum, through installation is passing more higher concentration of odourant. In one disposable action, to gas network, is added from 60 to $100 \mathrm{mg} \cdot \mathrm{m}^{-3}$ of compound.

\section{THT determination}

The main goal was to analyse the effectives of using the portable gas chromatograph in appointing the concentration of THT during tests. Research were made at the different measuring points in the city and its surroundings. In order to compare the work of a portable gas chromatograph with THT stationary analyser, the tests were performed at the same time for both devices on $28^{\text {th }}$ of May 2013 and on $28^{\text {th }}$ of October 2013.

The gas samples were taken from the gas installation to the Tedlar bag. Nengbing et al. proved, that Summa canister and Tedlar bags should been chosen for THT sampling - THT will not be stable in the aluminium bags and the glass syringes, because sulphide is easy adsorbed and oxidized by container surface [9].

The bags were connected to the gas chromatograph by a loop a moment before the test begin, in order to designate the concentration of odourant on the device the column A was selected and loaded with the library Assay ${ }_{\# 1}$ (THT). At the same time the stationary analyser was turn on to measure the concentration of odourant THT. The time to determent odourant for both devices was 15 minutes. The range of the THT determination by a Photovac Voyager is between 0.36 and $720 \mathrm{mg} \cdot \mathrm{m}^{-3}$ with the lower detection limit $0.18 \mathrm{mg} \cdot \mathrm{m}^{-3}$ (accuracy measurement $5 \%$ ), while by stationary analyser - between 5 and $100 \mathrm{mg} \cdot \mathrm{m}^{-3}$ (accuracy measurement $7 \%$ with a precision 2,8\%). Photovac Voyager analysis time was $3200 \mathrm{~s}$, oven temperature $60^{\circ} \mathrm{C}$. Loop injection time was $2 \mathrm{~s}$, while pump time - $20 \mathrm{~s}$ and backflush time - $1810 \mathrm{~s}$.

\section{Determination of odourised zone range}

Research were carried out to determine the range of odourised zone in the case where only one station is inserting higher concentration of THT to the gas network. The measuring points were selected in the city area and its surroundings. At this points the samples of the gas were taken to the Tedlar bags. The points were selected at the city centre, where the gas flow is the most even, and at the ends of the gas network - in the sat urban areas, where the concentration of the odourant is low.

There were 13 points chosen to research (Fig. 1). The first research began before over-odourised (higher concentration of the gas) was made, during the day on $14^{\text {th }}$ of August 2013 (Wednesday). The first series was performed to realize, what is the level of concentration of THT in the study area during normal, summer time.

On $30^{\text {th }}$ of August 2013 (Friday) the research had been repeated. Each time the numbered Tedlar bags were filled up with the gas samples. On $28^{\text {th }}$ of October 2013, over odourisation was made in some points of the city and its surroundings. The higher concentration of THT was added to the gas network from one of two odourised station. It was done in order to examine the tightness of the gas network before the upcoming heating season in winter. Raising the pressure of gas allows to capture leaks in places vulnerable to corrosion. In order to detect soft underbelly, it is necessary to implement increased doses of odourant. 


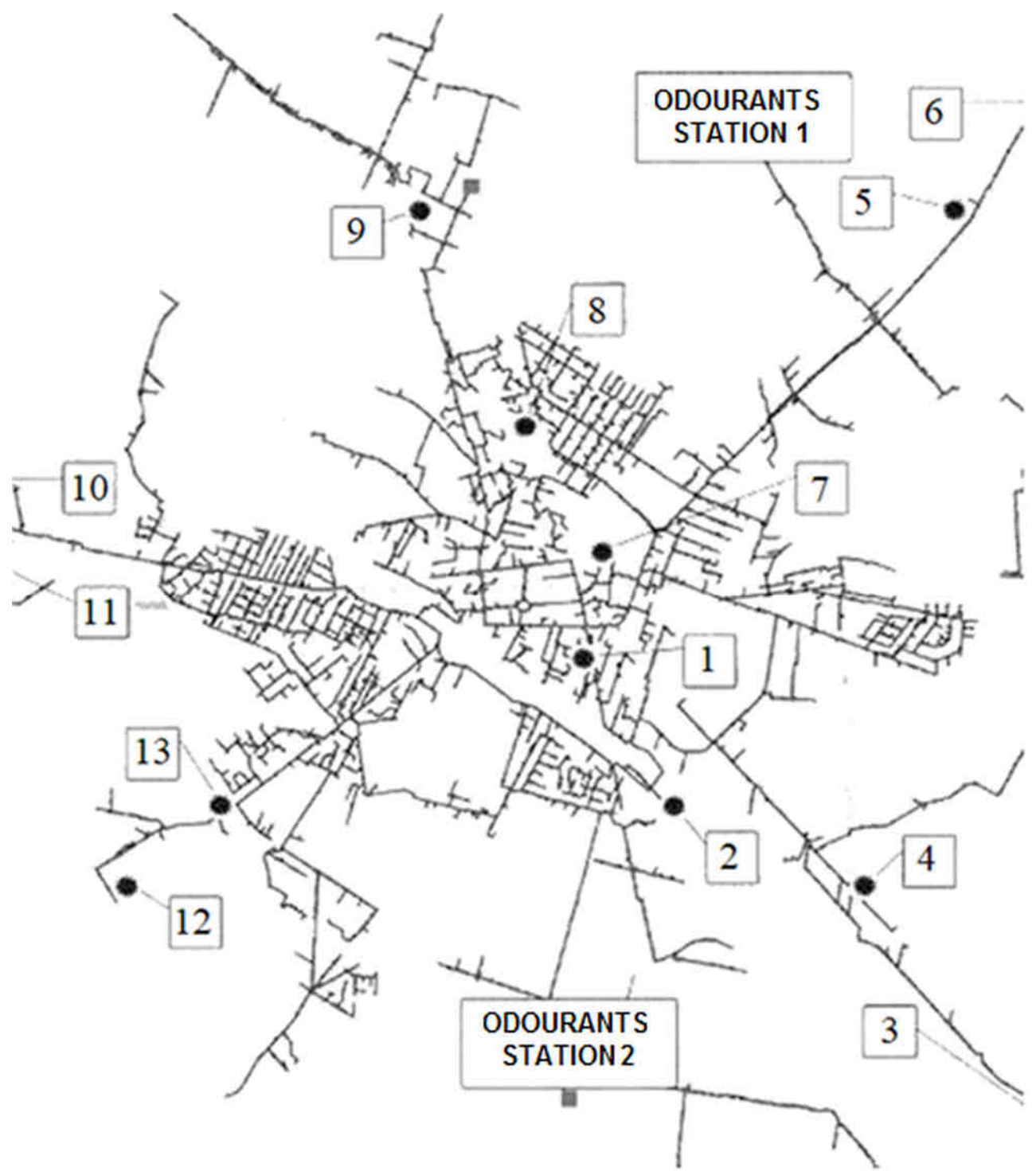

Fig. 1. Localization of measuring points in the gas network measuring points

The tests done on that day, were allowed to determine the functioning range of odourants at station number 2 which is localized at the south site of the city.

\section{Results}

In the first part, the samples of natural gas flowed through chromatographs columns. After 50 minutes, i.e. after adding all research results from three columns together, device has detected 20 compounds in natural gas. 11 of them had specified concentration. 
Tetrahydrothiophene was detected in columns A and B, at time lapse. Figure 2 shows the chromatogram with the exemplary results obtained from the column A, which is designated for heavy compounds and treated as pre-column.

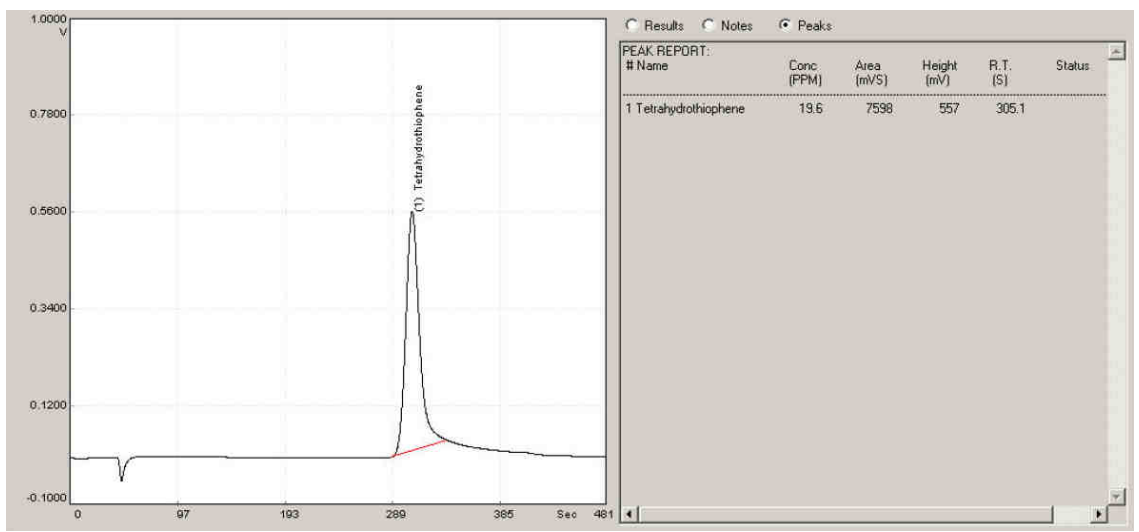

Fig. 2. The window of chromatogram obtained from samples research

At the retention time for the tetrahydrothiophene, $332.5 \mathrm{~s}$, there were not other compounds observed, that allows for precise cutting off the very peak of THT and assigned the concentration of the odourant. At the retention time, $847.1 \mathrm{~s}$, is observed compound 1,1,2,2-tetrachloroethane. As it can be seen, the concentration was larger than THT, although the peak was invisible and charted only by red line. This error is the result of a bad cut of the peak in the chromatogram by the program Site Chart.

The results of comparison between two kinds of THT analysers are shown in Table 2.

Comparison between portable gas chromatograph with stationary THT analyser

\begin{tabular}{|c|c|c|c|}
\hline \multirow{2}{*}{ Date of analysis } & \multicolumn{2}{|c|}{ THT concentration [ $\mathbf{m g} \cdot \mathbf{~ m}^{\mathbf{- 3}}$ ] } & \multirow{2}{*}{$\begin{array}{c}\text { Difference between } \\
\text { concentrations [\%] }\end{array}$} \\
\cline { 2 - 3 } & Stationary analyser ANAT-M & Photovac Voyager & 2.55 \\
\hline 28.05 .2013 & 37.60 & 38.56 & 1.91 \\
\hline 28.10 .2013 & 14.70 & 52.97 & \\
\hline
\end{tabular}

The results demonstrates the comparability of both devices to determine the concentration of THT odourant in the gas network. The percentage difference between the analyser and the gas chromatograph is contained in the margin of an error (7\%), which is established by the manufacturer of stationary analyser.

Schwinn was also dealing with the research of the concentration THT in the gas network and presented some examples of the odourant added to the gas network from the odourant stations. The obtained results showed the differences between the output concentrations of the odourant from the station and at the checkpoints. The highest percentage value of difference between results from odour station $\left(20.80 \mathrm{mg} \cdot \mathrm{m}^{-3}\right)$ and one of the checkpoint $\left(12.0 \mathrm{mg} \cdot \mathrm{m}^{-3}\right)$ was $42 \%$. In one case, concentration of THT in checkpoint $-20.80 \mathrm{mg} \cdot \mathrm{m}^{-3}$ - was higher than in the odour station $-22.0 \mathrm{mg} \cdot \mathrm{m}^{-3}$ [30]. 
Sonley wrote, that firstly, THT was used in pipelines just as it had been for reformed gas. Natural gas was injected by a dose up to $5 \mathrm{ppm}$ THT in high pressure (6 MPa) transmission pipes. However, gas samples further down the line, in the most cases had lost the THT odour. In in other cases, the gas developed different smell (for example beetroot odour) while retained only some of the chemical components. So, odourisation system had 'worked' in the local distribution network, but was imperfectly understood [1].

In order to determine the odourised zone in the city and its surroundings, 3 series of analyses were performed in 13 measuring points showed in Figure 1.

On $14^{\text {th }}$ of August 2013, the highest level of concentration of THT was recorded at the measurement point number 9 and it was $52.61 \mathrm{mg} \cdot \mathrm{m}^{-3}$. This point was located the closest to the odourant station number 1 . The lowest concentration was observed at the end of the gas network at the point number 11 and was $10.97 \mathrm{mg} \cdot \mathrm{m}^{-3}$. At the analysed point number 10 , although the odourant was noticeable in the air, THT concentration was not determined by a portable gas chromatograph.

The second largest concentration of odourant was detected in point number 5, at the end of the gas network. The measurements were made in the summer, when the need for gas is lower and its consumption is minimal. For this reason, THT in the gas grid could be accumulated.

On $30^{\text {th }}$ of August 2013 the next research had been carried out in order to check how odourised zone is spreading in the city and its surroundings. That day, the highest concentration of odourant was observed in the centre of the city at point number 1 and it was $35.27 \mathrm{mg} \cdot \mathrm{m}^{-3}$. Considering the locations of the points, it is difficult to determine, which of the odourised stations had greater influence in this area. The lowest concentration of THT was recorded at the point number 13 and it was $14.51 \mathrm{mg} \cdot \mathrm{m}^{-3}$.

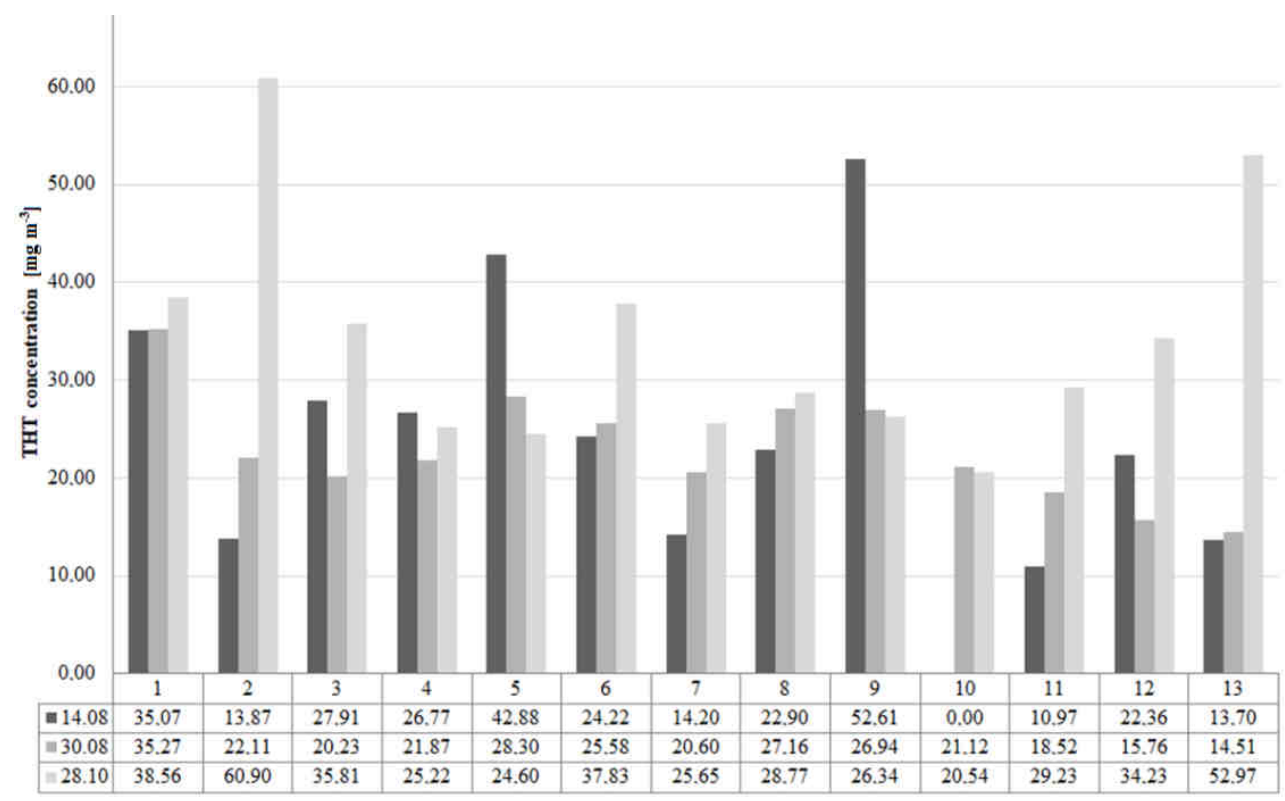

Fig. 3. Results of THT concentration in 3 series, in 13 measuring points 
The second largest odourant concentration was observed, like on $14^{\text {th }}$ of August, on the end of the gas network at the point number 5. Analysing all results obtained on this day, it is clear that the concentration of THT across the entire network was characterized by similar values.

On the $28^{\text {th }}$ October 2013 over-odourised was performed. The high amount of THT was added to gas installation from south odourants station (odourant station number 2). All obtained results are shown in Figure 3.

Based on the results recorded by portable gas chromatograph - Photovac Voyager, it was found that the highest concentration was observed at the city centre in the point number 2 and reached almost $61 \mathrm{mg} \cdot \mathrm{m}^{-3}$. The second highest concentration of odourant was appointed in the point number 13 which is placed nearby the south odourant station. The concentration in this area was almost $53 \mathrm{mg} \cdot \mathrm{m}^{-3}$. It should be noticed that these places are nearest to odourants station 2 . Behind the point 13 is point 12 . It must be deduced that if over-odourised was noticeable in measurement point 13, it is just as second one must be also supplied by the odourants station 2 . In the city centre there are three measurements points: 1, 7, 8. Based on these results, it is clear that point 1 is not representative. In these places, similar concentration of odourant was detected. As to the other points, located closer to the odourants station 1, over-odourised had not reached. The main of this result was probably a low gas flow in the gas installation.

Measuring points 5 and 6 are located on the end of the gas network and are powered mainly from odourants station 1. Despite of moderately high concentration of THT, these points are too far away from odourants station 2. It must be deduced that during the measurement, at the end of the installation, gas consumption was higher. This is the main result of increased need for gas by the consumers.

Considering the THT concentration in the measuring points 10 and 11 is not certain, which odourants station has greater range. Both points are located at the end of the gas network, but at the point 11 there is significantly higher concentration of odourant $\left(29.23 \mathrm{mg} \cdot \mathrm{m}^{-3}\right)$ than in point $10\left(20.54 \mathrm{mg} \cdot \mathrm{m}^{-3}\right)$. Probably in the point 11 the analogous situation occurred as it was discussed above in point 6 .

Based on this analysis, the simulation gas network was prepared for the city and its surrounding area divided into zones odouration (Fig. 4). The perimeter of range for two stations was separated by thick red line. With the obtained research results, in the crosshatch area, is not possibility to choose only one odourant station which is more dominant there. It is assumed that the both odourants station show their activity.

As Usher wrote, the reduction in the odourant concentration in transported gas is not a new problem, and the odour causes may be the result of odour "fatigue" [11]. However, in some cases it can be the result of people adaptation of the odourant smell. Usher noticed, that odour fade occurs because of physical and chemical processes, important to consider when identifying potential issues [11].

The processes involved are: adsorption, absorption and oxidation. Also Saadatmand et al. [5] investigated possible physical-chemical mechanisms responsible for odour fading, using X-ray photoelectron spectroscopy (XPS) and gas chromatography used to check the interactions of tertiary butyl mercaptan (TBM) with the pipe material. The researchers found that by increasing pressure, rusted pipe surface and temperature or by decreasing the gas flow rate and odourant concentration the mercaptan removal was increased [5]. Therefore, Seguel et al. [31] wrote, that the odourant concentration emanating from the odourised liquid is not uniform in the vapours released, and the gas will also be much 
leaner than the odourised liquid. Those authors recommend analysing the odourant directly from the liquid phase [31]. Gross et al. [32] examined a numerical modelling of a pulse train diffusion, representing injection of the odorant in gas pipeline. Researchers proved, that Reynolds Average Navier-Stokes (RANS) equations with the $k-\varepsilon$ turbulence model show a strong agreement for the experimental data from a real pipeline. Similar results achieved Tukmakov et al. [33] using model built on the basis of built on the basis of the system of motion of viscous, compressible, heatconducting, two-component medium with account for the odorant diffusion. Also, Nagaresh et al. [34] used mass transfer model, correlated for bibble diameter estimation, and SVM-based model. Researchers wrote, that experimental data and controller calculations for odourant cumulative mass transfers showed absolute error values between 0.4 and $9.10 \%$.

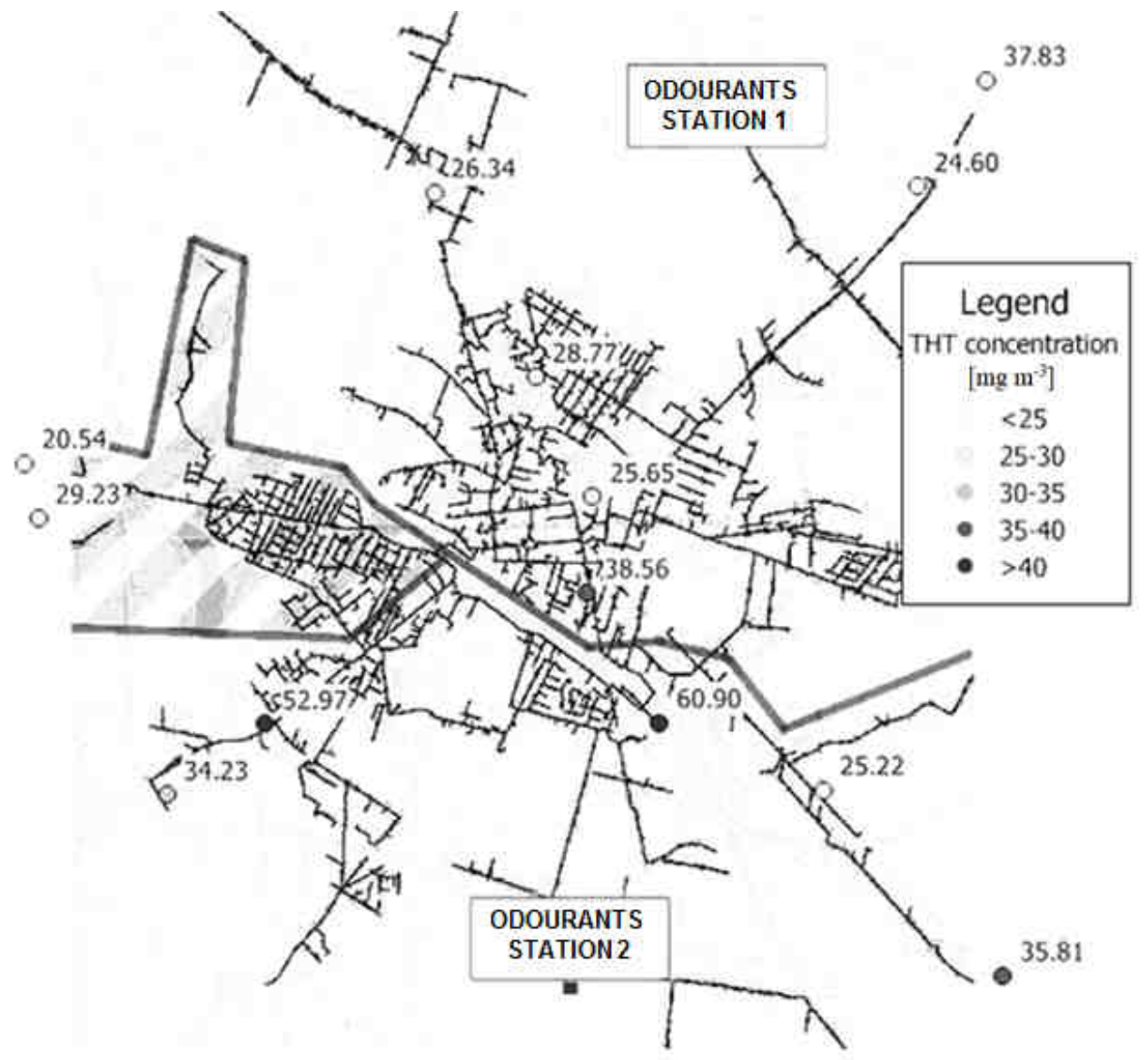

Fig. 4. Simulation of gas network with marked points of measurement

\section{Conclusions}

Many researchers wrote about assessing of risk associated with $\mathrm{CO}_{2}$ and natural gas pipelines [1, 35-38]. However, when addressing pipelines risk issues, very important is 
public perception [39]. It is extremely important to trace the leaks in gas systems at considerably low concentrations of gas in air [40].

This study shows, that portable gas chromatograph - Photovac Voyager is an analyser that can be successfully used for monitoring the concentration of THT in the gas network. Due to a very high sensitivity, this device allows to perform meaningful analysis by separating the multiple chemical compounds, without knowledge of their quantity and type. After series of tests, it transpired that Voyager detected, identified and defined the level of odourant concentration and also noted the presence of the other chemicals, which are also components of the gas network.

The objective, after the first step, was taken to determine the effectiveness of the use of portable gas chromatograph for monitoring gas network and to compare it with working stationary THT analyser. The results confirmed the functionality of the chromatographs, since the differences between both devices were in the range of 1.91-2.55\%. This demonstrates the compatibility of the two equipments in analysing the concentration of odourant - THT in the gas network. The percentage differences between the analysers are in the margin of error $(7 \%)$, which is established by the manufacturer of stationary analyser.

In order to determine the odourised zone for the city, three series of tests were performed with using a portable gas chromatograph - Voyager. The material for analysing was obtained from 13 measurement points disposed in the city area and its surroundings. Odourant in the gas network is a substance difficult to analyse due to its physicochemical properties. Very important is, that the gas consumption by customers is unstable. In times of reduced gas consumption, THT is to sink to the bottom of the pipe and accumulates in specified points. This problem often occurs in the summer time, when the gas consumption is reduced due to the holiday. When the gas flow increases, the accumulated odourant is picked up from the bottom of the installation and then it reaches much higher concentrations than those that are added from odourised stations.

A similar situation is apparent very often at the ends of the gas network, where gas consumption by consumers is much less. In these places, the concentration of THT is lower. This is connected to a low pressure of gas in the pipe. With a view of this situation, the dosage of odourant should be clearly detectable at the ends of gas installation (odour intensity $I=2$ ). To represent the complete case about over-odourised, the research should be repeated in different distance of time. Odourise which come from odourants station does not spread immediately THT to entire city. The higher concentration of odourant could be an effect of larger dose of THT added from odourants station or from the accumulation of the gas in the gas pipe. This issue occurs at the ends of the gas network, where gas consumption by consumers is low.

\section{Acknowledgements}

The authors thank the management and workers of Polska Spolka Gazownictwa sp. $\mathrm{z}$ o.o. (Polish Gas Company) for allowing the examinations on objects of the gas network and the provision of materials necessary for the research and descriptions of the results.

\section{References}

[1] Kilgallon R, Gilfillan SMV, Haszeldine RS, McDermott CI. Odourisation of $\mathrm{CO}_{2}$ pipelines in the UK: Historical and current impacts of smell during gas transport. Int $\mathrm{J}$ Greenhouse Gas Control. 2015;37:504-512. DOI: 10.1016/j.ijggc.2015.04.010. 
[2] Alpekin G, DeVoss S, Dubovik M, Monroe J, Amalfitano R, Israelson G. Regenerable sorbent for natural gas desulfurization. J Materials Eng Performance. 2006;15,4. DOI: 10.1361/105994906X117251.

[3] Tenkrat D, Prokes O, Hlincik T. Natural Gas Odorization. Shanghai: INTECH Open Access Publisher; 2010. DOI: $10.5772 / 9825$.

[4] Amirbekyan D. Natural gas odorization monitoring for safety and consistency. Pipeline Gas J. 2013;240:12. https://pgjonline.com/magazine/2013/december-2013-vol-240-no-12/features/natural-gas-odorizationmonitoring-for-safety-and-consistency.

[5] Saadatmand M, Foroughi H, Dai T, Misra T, Bensabath T, Farnood R. Odor fading in natural gas distribution systems. Process Safety Environ Protect. 2015;94:131-139. DOI: 10.1016/j.psep.2015.01.005.

[6] Tukmakov L, Mubarakshin BR, Tonkonog VG. Simulation of the process of odorizing a natural gas. J Eng Phys Thermophys. 2016; 89(1):135-140. DOI: 10.1007/s10891-016-1360-5.

[7] Capelli L, Sironi S, Del Rosso R. Evaluation of olfactory properties of gas odorants. Chem Eng Transact. 2014;36:301-306. DOI: 10.3303/CET1436051.

[8] Seguel R, Mancilla C, Sakamoto PA. Continuous measurement of odorant composition for liquefied petroleum gas. Chem Eng Transact. 2018;68:331-336. DOI: 10.3303/CET1868056.

[9] Xu N, Ying H, Zhu L. Determination of tetrahydrothiophene in ambient air by gas chromatography with a PFPD detector coupled to a preconcentration technology. Proc 13th World Clean Air Environ Protect Congress Exhibit. London; 2004. https://pdfs.semanticscholar.org/6587/ a75286dd2cde8b98752ba0f0115aaf0a32f4.pdf.

[10] Tetrahydrothiophen The MAK Collection for Occupational Health and Safety; 2012: 291-303. DOI: 10.1002/3527600418.mb11001e0026a.

[11] Usher MJ. Odor Fade-Possible Causes and Remedies. Proc No. 285. Gas Measurement School. Ontario, CA, Canadian Gas Assoc.1999. https://pscfiles.tamu.edu/library/online-library/odorfadecause.pdf.

[12] Nagata Y. Measurement of odor threshold by Triangle Odor Bag Method. Annual Meet Odour Res Eng Assoc; 2003. http://cschi.cz/odour/files/world/Measurement $\% 20$ of $\% 20$ odor $\% 20$ threshold $\% 20$ by $\%$ 20Triangle\%20Odor\%20Bag\%20Method.pdf.

[13] Hennings U, Reimert R. Behaviour of sulfur-free odorants in natural gas fed PEM fuel cell systems. Fuel Cells. 2007; 7:63-69. DOI: 10.1002/fuce.200500222.

[14] Ruzsanyi V, Sielemann S, Baumbach JI. Detection of sulfur-free odorants in natural gas using ion mobility spectrometry. J Environ Monit. 2007;9(1):61-65. DOI: 10.1039/b613951e.

[15] Langford VS, McEwan MJ, Askey M, Barnes H, Olerenshaw JG. Comprehensive instrumental odor analysis using SIFT-MS: a case study. Environments. 2018;5(4),43. DOI: 10.3390/environments5040043.

[16] Yashin YI, Yashin AY. Miniaturization of gas-chromatographic instruments. J Analyt Chem. 2001;56(9):794-805. DOI: 10.1023/A:1016795926329.

[17] Henry C. Micro Meets Macro: Interfacing microchips and mass spectrometers. Anal Chem. 1997;69:359A-361A. DOI: 10.1021/ac971659z.

[18] Belgiorno V, Naddeo V, Zarra T. Odour Impact Assessment Handbook. New Jersey: John Wiley Sons, Inc; 2013. ISBN: 9781119969280.

[19] Guz Ł, Łagód G, Jaromin-Gleń K, Suchorab Z, Sobczuk H, Bieganowski A. Application of gas sensor arrays in assessment of wastewater purification effects. Sensors. 2015;15(1):1-21. DOI: 10.3390/s150100001.

[20] Bourgeois W, Romain AC, Nicolas J, Stuetz RM. The use of sensor arrays for environmental monitoring: interests and limitations. J Environ Monit. 2003;5(6):852-860. DOI: 10.1039/B307905H.

[21] Gottlieb J. Field Screening Europe. Netherlands: Kluwer Academic Publishers; 1997. ISBN: 9400914733.

[22] Djogo M, Kiurski J, Adamović D, Vojinović Miloradov M, Radonić J, Turk-Sekulic M. Hazardous air pollutants (HAPs) in printing facility in Novi Sad. Annals Faculty Eng Hunedoara - Int J Eng. 2011;9:101-104. http://annals.fih.upt.ro/pdf-full/2011/ANNALS-2011-4-21.pdf.

[23] De Nijs RCM, van Dalen J, Smit ALC, van Loo EM. Fast on-site determination of tetrahydrothiophene in natural gas with a portable micro gas chromatograph: A feasibility study. J High Resol Chromatogr. 1993;16(6):379-380. DOI: 10.1002/jhrc.1240160610.

[24] Gantt B, Meskhidze N, Kamykowski D. A new physically-based quantification of marine isoprene and primary organic aerosol emissions. Atmos Chem Phys. 2009;9:4915-4927. DOI: 10.5194/acp-9-4915-2009.

[25] Geron C, Guenther A, Greenberg J, Loescher H, Clark D, Baker B. Biogenic volatile organic compound emissions from a lowland tropical wet forest in Costa Rica. Atmosph Environ. 2002;36. DOI: 10.1016/S1352-2310(02)00301-1.

[26] Funk J, Jones C, Baker C, Fuller H, Giardina C, Lerdau M. Diurinal variation in the basal emission rate of isoprene. Ecol Applications. 2003;13(1). DOI: 10.1890/1051-0761(2003)013[0269:DVITBE]2.0.CO;2.

[27] Karl T, Potosnak M, Guenther A, Clark D, Walker J, Herrick JD, et al. Exchange processes of volatile organic compounds above a tropical rain forest: Implications for modeling tropospheric chemistry above dense vegetation. J Geophys Res. 2004;109:D18306. DOI: 10.1029/2004JD004738. 
[28] De Hate R, Skelly B, Bourgeois M, Desai U, Giffe T, Johnson T, et al. Managing public health risks using air monitoring at a former manufactured gas plant site. J Environ Protect. 2014;5:1400-1405. DOI: 10.4236/jep.2014.514133.

[29] Huszał A. Nawanianie paliw gazowych gwarancją ich bezpiecznego użytkowania (Odourising gas fuels guarantees their safe use). Nafta-G $\square$. 2017;73(11):878-886. DOI: 10.18668/NG.2017.11.08.

[30] Schwinn A. Techniki nawaniania gazu ziemnego (Odourising techniques for natural gas). In: Wójtowicz A, Nawrocka-Fuchs B, editors. Historia gazownictwa polskiego od połowy XIX wieku po rok 2000 (The history of Polish gas industry from the mid-nineteenth century to the year 2000). Warszawa: Polskie Zrzeszenie Inżynierów i Techników Sanitarnych. Zarząd Główny; 2002. ISBN: 8387792225.

[31] Seguel R, Mancilla C, Sakamoto P. Continuous measurement of odorant composition for liquefied petroleum gas. Chem Eng Tr ns. 2018;68:331-336. DOI: 10.3303/CET1868056.

[32] Gross R, Fontana E, Silva A, Quadri MB, Souza SMAGU. Dispersion of odorants in natural gas distribution networks. He $\square \mathrm{M} \ s \mathrm{~s} \operatorname{Tr} \backsim$ nsfer. 2018;54(9):2827-2834. DOI: 10.1007/s00231-018-2323-5.

[33] Tukmakov AL, Mubarakshin BR, Tonkonog VG. Simulation of the process of odorizing a natural gas. J Eng Phys Thermophys. 2018;89(1). DOI: 10.1007/s10891-016-1360-5.

[34] Negaresh M, Farrokhnia M, Mehranbod N. Modeling and control of natural gas bypass odorizer. J Nat Gas Sci Eng. 2017;50. DOI: 10.1016/j.jngse.2017.12.010.

[35] Koers P, de Looij M. Final public report: Safety study for liquid logistics shipping concept. Prepared by DNV for Vop $\_$/Anthony Veder; 2010. https:/hub.glob $\square c c s i n s t i t u t e . c o m / s i t e s / d e f \_u l t / f i l e s / p u b l i c$ tions/ 19006/final-public-report-safety-study-liquid-logistics-shipping-concept.pdf.

[36] Cleaver P, Hopkins $\mathrm{H}$. The application of individual and societal risk assessment to $\mathrm{CO}_{2}$ pipelines. J Pipeline Eng. 2012;11:191-199. http://www.pipemag.com/publications/journal/currentSample/ JPE\%20Sept\%202012\%20-\%20sample\%20issue.pdf.

[37] Knoope MMJ, Raben IME, Ramírez A, Spruijt MPN, Faaij APC. The influence of risk mitigation measures on the risks, costs and routing of $\mathrm{CO}_{2}$ pipelines. Int $\mathrm{J}$ Greenhouse $\mathrm{G} \triangleleft \mathrm{s}$ Control. 2014;29:104-124. DOI: 10.1016/j.ijggc.2014.08.001.

[38] Zanchettin C, Almeida LM., de Menezes FD. An intelligent monitoring system for natural gas odorization. IEEE Sensors J. 2015;15,1. DOI: 10.1109/JSEN.2014.2345476.

[39] Jo YD, Crowl DA. Individual risk analysis of high-pressure natural gas pipelines. J Loss Prev Process Ind. 2008;21:589-595. DOI: 10.1016/j.jlp.2008.04.006.

[40] Liszka K, Łaciak M, Oliinyk A. Analysis of new generation odorants applicability in the Polish natural gas distribution network. AGH Drilling, Oil, Gas. 2014;31,1. DOI: 10.7494/drill.2014.31.1.59. 